\title{
Environmental-based budget planning in The Tegal Regency Government
}

\author{
Mohamad Heri Hidayattuloh ${ }^{1, *}$, Azis Nur Bambang ${ }^{2}$, and A Amirudin ${ }^{3}$ \\ ${ }^{1}$ Master Program in Environmental Science, Diponegoro University, 50275 Semarang, Indonesia \\ ${ }^{2}$ Faculty of Fisheries and Marine Sciences Diponegoro University, 50275 Semarang, Indonesia \\ ${ }^{3}$ Department of Anthropology, Faculty of Humanity, Diponegoro University, 50275 Semarang, Indonesia
}

\begin{abstract}
Environmental problems in Tegal Regency have become complex and not handled well. Some of the factors causing environmental problems that have not been handled properly are the low commitment of the regional government to prioritize environmental interests in regional development priorities and the low awareness of the community towards the environment. However, budget allocation for environmental sector is still considered low, i.e. $1.48 \%$. This low budget allocation requires a priority scale to overcome environmental problems in Tegal Regency. This study aims to determine priorities in sectors and policies in environment-based budgeting in the Tegal Regency Government. The research method used is a quantitative approach. The analytical tool used is the Analytical Hierarchy Process (AHP) method with the help of Expert Choice. Based on the results of the study that the waste sector is a priority sector and the procurement of garbage trucks is a policy priority in environment-based budget planning in the Tegal Regency Government
\end{abstract}

Keywords: environmental problems; budget allocation; waste.

\section{Introduction}

Nowadays, the world is facing a blast in human population. Based on the data from the United Nations (UN), the human population in the world in 2017 is about 7.6 billion lives and will increase to be 8.6 billion lives in 2050 [1]. The increase of human population in the world which is fast causes some problems. Every person needs to fulfill their daily needs to survive, starting from primary needs to the tertiary needs. The demands of stuff, services, and residences increase, but nature as the supplier of those needs is limited. The use of natural resources which is uncontrollable causes the world facing enormous environmental damage.

Sustainable development is a global issue which is spoken widely when talking about the process of development. In the process to achieve the target of development, all of potencies and resources possessed by a country are used as optimal as possible. The use of the resources should concern the factor of the conservation of bio environment. The use of the resources which tend to be explorative will cause problems in the process of the development itself [2]. These problems need to be overcome by a concept of sustainable development consisting of an understanding of the use of bio environment fairly and wisely so that the environment will always be conserved well.

The concept of policy on the environment has basically been contained in Law Number 32 of 2009 of Environmental Protection and Management. In articles 44 and 45 of Law Number 32 of 2009 concerning Protection and Management of the Environment consists of the duties of central and regional government to prepare the budget for the program realization and development activity concerning the environmental aspect and the management of environment. The regional government which performs the protection and management of environment must get the budget compensation from central government in the form of Special Allocation Funds (DAK).

The budget allocation for the conservation of environment in the regulation is not stated clearly because it does not state the percentage of the allocation. The inexistence of the percentage of the allocation quantitatively causes this bio environment allocation having no standard which is certain and clear so that the point of view in seeing this regulation tends to be multi perspectives. Furthermore, the budget allocation for the conservation of environment by regional government is stated as the political will from the executive and legislative [3]. The effect of this uncertainty in the budget allocation by Law Number 32 of 2009 and added by the factor of economic development which tends to focus on the economic development make this environmental problem becomes more critical.

This complex environment problem must be solved by giving certain budget allocation as the problem solver of the government. In APBN, the budget allocation for the conservation of environment is still low. Besides still low in percentage, the budget allocation has not focused on the main problem yet and only done as programs and supporting activities in environmental problem-solving. According to

\footnotetext{
* Corresponding author: hidayattulohmohamadheri@gmail.com
} 
data from the Tegal Regency Environmental Agency, in the 2016-2018 range of budget allocations for the environment an average of $1.5 \%$ of the Tegal Regency budget per year, whereas the Tegal Regency Environmental Quality Index in 2017 was 63.78 lower than National IKLH amounts to 66.46 [4].

Table 1. Budget allocation for Tegal Regency Environmental Agency 2015-2019

\begin{tabular}{|c|c|c|c|}
\hline No & Year & $\begin{array}{c}\text { Budget Amount } \\
\text { (Rp) }\end{array}$ & Percentage \\
\hline 1 & 2015 & 3.844 .923 .000 & $0,50 \%$ \\
\hline 2 & 2016 & 3.880 .960 .000 & $0,37 \%$ \\
\hline 3 & 2017 & 12.455 .000 .000 & $1,42 \%$ \\
\hline 4 & 2018 & 19.985 .000 .000 & $1,65 \%$ \\
\hline 5 & 2019 & 18.296 .282 .000 & $1,49 \%$ \\
\hline
\end{tabular}

Budgeting is a dominant factor in the process of developing a region, one example of budgeting is the budget allocation of environment for the importance of preventing, recovering, and improving the quality of environment which is affected by the negative effect of the developing process in a region. In the ideal practice of the arrangement of the budget, there is an important factor that should be concerned, i.e. planning and budgeting. Therefore, the process of planning and budgeting must be done by involving whole stakeholders and also involving the participation of society. However, practically, there are some problems in the process of planning and budgeting of a region causing negative effects for the effort of environment conservation.

The commitment of regional government for prioritizing the importance of environment as the priority of regional development is the most important factor in the effort of environment conservation in a region. The lack of the commitment will affect the quality of the policy made and the quantity of budget allocated to the environmental sector.

In the process of the arrangement of planning and budgeting, the point of view of the stakeholders affects the result of the budget allocation. Shrivastava in Hadi [5] divided the point of view into two sides. The traditional point of view (anthropocentric) and exocentric point of view (biocentrism). Reviewed from the purpose, a traditional point of view focuses on economic development, financial benefit, and elite's importance. However, biocentrism orientates in the continuity of life and the importance of society.

According to Faqih [3], the way of thinking as stated by Shrivastava can be used to differ the models of planning the policy in a governmental institution. In a governmental institution possessing an anthropocentric point of view, this institution uses hierarchical structure pattern, decision making is "top-down", and authorization control is focused on an individual so that the implication is on the high disparity of income in the society. Anthropocentric and biocentrism point of view in environment ethics according to Keraf [6] are stated as shallow ecology dan deep ecology.

Environmental based budget is a response to the condition of the development which decreases the support for environmental resources related to the next generation. Green budgeting can be considered as a stimulant to awaken the social roles in the efforts of the improvement of sustainable development [7].
Environmental based budget planning in Tegal Regency which is based on APBD Tegal Regency in 2019 is considered allocated well. This green budgeting planning aims to manage, prevent, and rehabilitate the damages in environment in Tegal Regency. However, the amount of budget allocation still needs to be improved in the way of its portion. This is caused by the environmental problems in Tegal Regency which should be handled are more complicated and complex. Besides the portion of the budget which should be increased, the strategy of taking the priority is also needed to make policy in environmental sector so that the budget allocation can be beneficial and give a real impact in preventing, recovering, and improving the quality of environment in Tegal Regency.

Priority is an attempt to overestimate things from other things. Priority is a process in decision making that is considered as the most important aspect with the support of commitment to implement the decision. The determination of priorities must be based on certain criteria.

The purpose of this study is to determine sector priorities and policies in environment-based budgeting in the Tegal Regency Government. This research is expected to be used as input for local governments in implementing environmentalbased budget planning in the government bureaucracy.

To determine sector and policy priorities it is necessary to assign weight values to the criteria, then proceed with a ranking process that will select the alternatives given. The determination of alternatives must be systematic and use a decision support system. the decision-making method used is the Analytical Hierarchy Process [8] and using Expert Choice as the software..

\section{Research Methods}

This research is a quantitative research using Analytical Hierarchy Process (AHP) method as its analytical device and also using Expert Choice as the software.

This research was conducted using judgment sampling or purposive sampling technique. Purposive sampling is a technique in collecting data with a certain consideration [9]. The research sampling was intentionally taken in order to get specific and accurate information related to the decision making in the budgeting policy.

This research used 18 respondents which are related to the decision making in the budgeting policy. According to [10], research using the AHP method does not need the minimum requirement related to the respondents, but just the people who are policymakers and experts in environment. The respondents are shown in Table 2 below.

Table 2. Respondents' Sample Data

\begin{tabular}{|c|l|l|c|}
\hline No & \multicolumn{1}{|c|}{ Sectors of } & \multicolumn{1}{|c|}{ OPD } & Qnt \\
\hline 1. & Agriculture & $\begin{array}{l}\text { Agriculture and Food } \\
\text { Security Agency }\end{array}$ & 1 \\
\hline 2. & Infrastructure & $\begin{array}{l}\text { 1. Public Works Agency } \\
\text { 2. Public Housing, Settlement } \\
\text { Area, Spatial Planning and } \\
\text { Land Agency }\end{array}$ & 2 \\
\hline 3. & City & 1. Public Works Public & 2 \\
\hline
\end{tabular}




\begin{tabular}{|c|c|c|c|}
\hline & & $\begin{array}{l}\text { 2. Agency Housing, } \\
\text { Settlement Area, Spatial } \\
\text { Planning and Land Agency }\end{array}$ & \\
\hline 4. & Fishery & $\begin{array}{l}\text { Fisheries and Animal } \\
\text { Husbandry Agency }\end{array}$ & 1 \\
\hline 5. & Industry & Industry and Labor Agency & 1 \\
\hline 6. & Tourism & $\begin{array}{l}\text { Tourism, Youth and Sports } \\
\text { Agency }\end{array}$ & 1 \\
\hline 7. & Transportation & Transportation Agency & 1 \\
\hline 8 & Waste & Environmental Agency & 1 \\
\hline 9. & Water & $\begin{array}{l}\text { 1. Public Works Agency } \\
\text { 2. Environmental Agency }\end{array}$ & 2 \\
\hline 10. & Bappeda & & 4 \\
\hline 11. & $\begin{array}{l}\text { DPRD } \\
\text { members }\end{array}$ & & 2 \\
\hline
\end{tabular}

In the research stage, after identifying problems and studying the literature, the criteria and alternatives were arranged. The criteria in this are shown in Table 3 below.

Table 3. Criteria for environment-based budgeting priority sectors

\begin{tabular}{|c|l|l|}
\hline No & \multicolumn{1}{|c|}{ Criteria } & \multicolumn{1}{c|}{ Information } \\
\hline 1. & Actual & Get public attention \\
\hline 2. & Urgent & Must get immediate treatment \\
\hline 3. & Significant & $\begin{array}{l}\text { Potential impact on the public } \\
\text { community }\end{array}$ \\
\hline 4. & Consistent & $\begin{array}{l}\text { In accordance with the main tasks and } \\
\text { functions of the organization and } \\
\text { regional policies }\end{array}$ \\
\hline
\end{tabular}

For alternatives that become priority sectors in environment-based budgets are shown in Table 4 .
Table 4. Alternative sectors for environment-based budgeting priority sectors

\begin{tabular}{|l|l|c|}
\hline No & \multicolumn{1}{|c|}{ Alternative } & Code \\
\hline 1. & Agriculture & S1 \\
2. & Infrastructure & S2 \\
3. & City & S3 \\
4. & Fisheries & S4 \\
5. & Industry & S5 \\
6. & Tourism & S6 \\
7. & Transportation & S7 \\
8. & Waste & S8 \\
9. & Water & S9 \\
\hline
\end{tabular}

The alternative refers to 11 aspects of the United Nation on Environment Program (UNEP) in a Green Economy [11]

For alternatives that are priority policies in environmental-based budgeting are shown in Table 5.

Table 5. Alternative policies for environment-based budgeting priority sectors

\begin{tabular}{|c|l|c|}
\hline No & \multicolumn{1}{|c|}{ Alternative policies } & Code \\
\hline 1. & $\begin{array}{l}\text { Developing and expanding the organic farming } \\
\text { region }\end{array}$ & P1 \\
\hline 2. & $\begin{array}{l}\text { Constructing a pedestrian and green line on the } \\
\text { sidewalks }\end{array}$ & P2 \\
\hline 3. & Constructing Green Open Space & P3 \\
\hline 4. & Conserving coral reefs & P4 \\
\hline 5. & $\begin{array}{l}\text { Hazardous and Toxic Substances Waste } \\
\text { Management }\end{array}$ & P5 \\
\hline 6. & Developing eco-tourism & P6 \\
\hline 7. & Improving public transportation facilitations & P7 \\
\hline 8. & Procurement of garbage trucks & P8 \\
\hline 9. & $\begin{array}{l}\text { Procurement of Rural Drinking Water } \\
\text { Installation Facilities and Infrastructure }\end{array}$ & P9 \\
\hline
\end{tabular}

The next step is to create a hierarchical structure from the decision model as shown in Figure 1 and Figure 2. Then make a pairwise comparison between each criterion and alternative, so that the value of the importance of each criterion and alternative is obtained in the form of qualitative opinions.

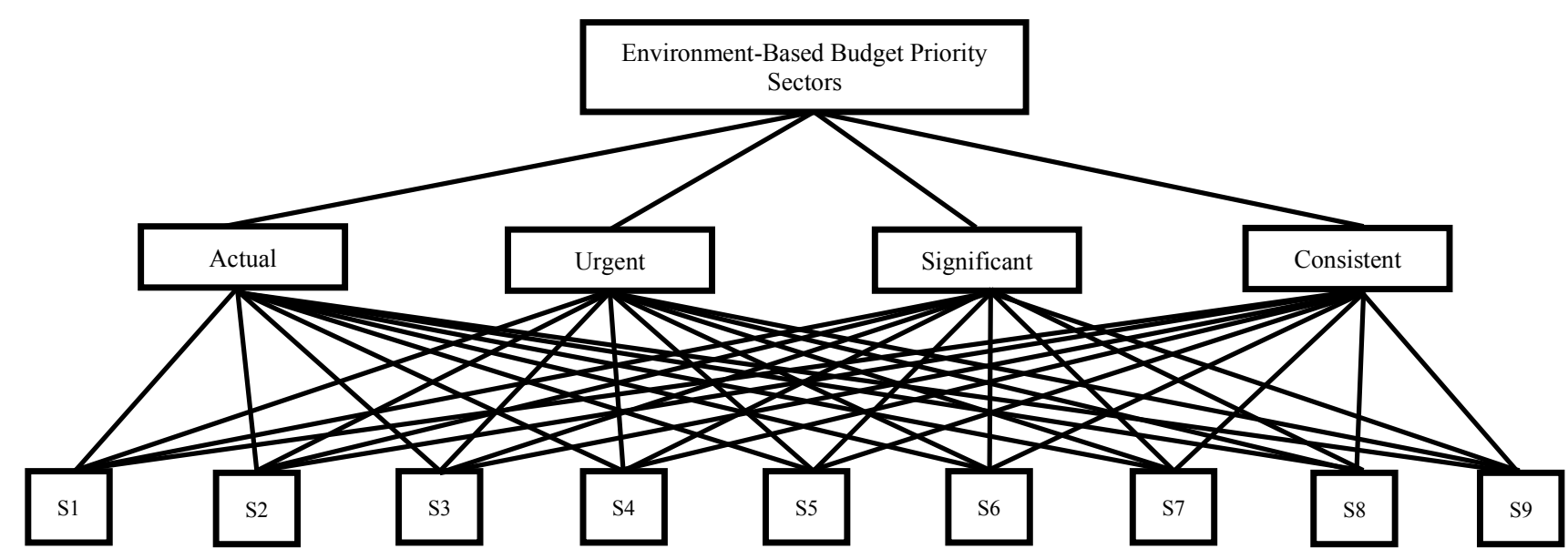

Fig. 1. AHP priority sectors model 


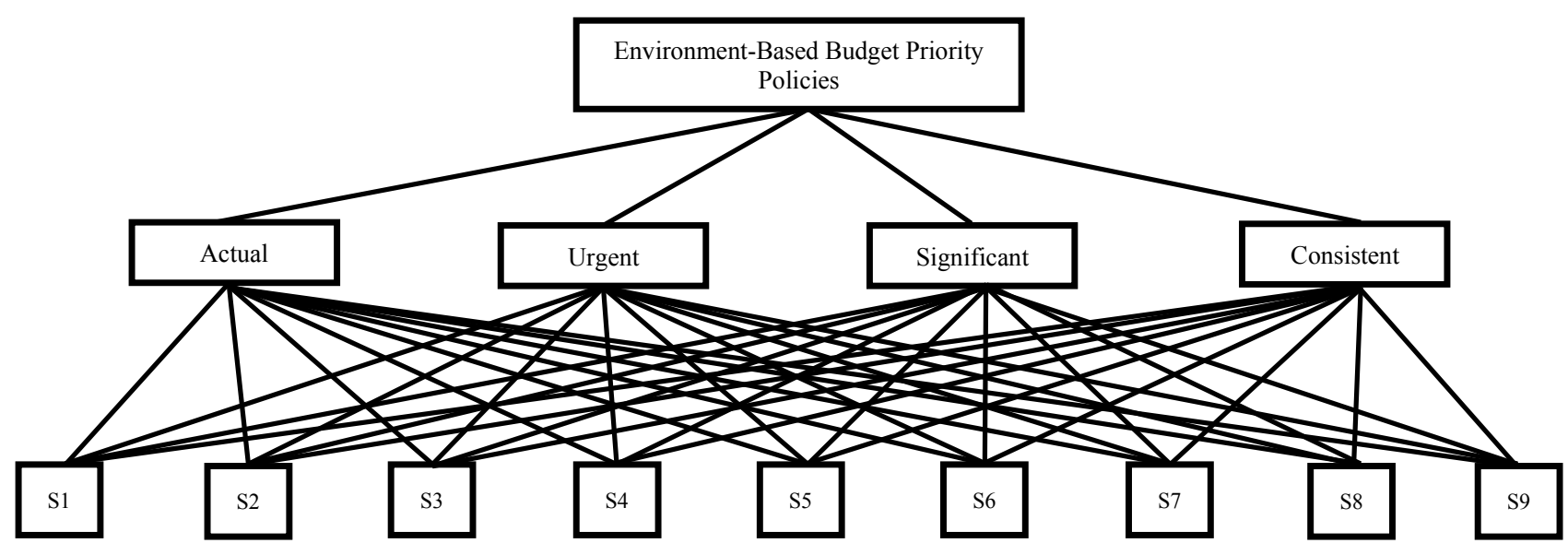

Fig. 2. AHP priority policies model

To change the qualitative to quantitative opinion, the rating scale is used so that opinion values will be obtained in the form of numbers (quantitative). Relative comparison values are then processed to determine the relative rank of all alternatives. The numerical values imposed for all comparisons are obtained from the comparison scale of 1 to 9 that has been set by Saaty [10] as in table 6

Table 6. Pairing Comparative Assessment Scales

\begin{tabular}{|c|l|l|}
\hline No & Score & \multicolumn{1}{c|}{ Information } \\
\hline 1. & 1 & $\begin{array}{l}\text { both elements/alternatives are equally } \\
\text { important }\end{array}$ \\
\hline 2. & 3 & $\begin{array}{l}\text { One element is slightly more important than } \\
\text { the other }\end{array}$ \\
\hline 3. & 5 & $\begin{array}{l}\text { One element is more important than the } \\
\text { other }\end{array}$ \\
\hline 4. & 7 & $\begin{array}{l}\text { One element is very important than other } \\
\text { elements }\end{array}$ \\
\hline 5. & 9 & $\begin{array}{l}\text { One absolute element is more important } \\
\text { than the other elements }\end{array}$ \\
\hline 6. & $2,4,6,8$ & $\begin{array}{l}\text { Values between two values are contiguous } \\
\text { considerations }\end{array}$ \\
\hline
\end{tabular}

The next step is to create a paired comparison matrix that describes the impact of the elements on the criteria at the top level so that all considerations are $n \times\{(n-1) / 2\}$, where $n$ is the number of elements compared.

Table 7. Pairwise Comparison Matrix

\begin{tabular}{|l|l|l|l|l|l|}
\hline $\mathbf{C}$ & \multicolumn{1}{|c|}{$\mathbf{A}_{1}$} & $\mathbf{A}_{2}$ & \multicolumn{1}{|c|}{$\mathbf{A}_{3}$} & & $\mathbf{A}_{\mathbf{n}}$ \\
\hline $\mathbf{A}_{1}$ & $\mathrm{~A}_{11}$ & $\mathrm{a}_{12}$ & $\mathrm{a}_{13}$ & & $\mathrm{a}_{1 \mathrm{n}}$ \\
\hline $\mathbf{A}_{2}$ & $\mathrm{a}_{21}$ & $\mathrm{a}_{22}$ & $\mathrm{a}_{23}$ & & $\mathrm{a}_{2 \mathrm{n}}$ \\
\hline $\mathbf{A}_{3}$ & $\mathrm{a}_{31}$ & $\mathrm{a}_{31}$ & $\mathrm{a}_{31}$ & & $\mathrm{a}_{3 \mathrm{n}}$ \\
\hline & & & & & \\
\hline $\mathbf{A n}$ & $\mathrm{a}_{\mathrm{n} 1}$ & $\mathrm{a}_{\mathrm{n} 2}$ & $\mathrm{a}_{\mathrm{n} 3}$ & & $\mathrm{a}_{\mathrm{nn}}$ \\
\hline
\end{tabular}

After the weighting of the criteria is obtained then consistency checking is done for the pairwise comparison matrix. If more than 0.1 then a pairwise comparison must be made until the ratio is less than or equal to 0.1 (consistent). A similar thing is also done for each comparison matrix between alternatives.

The synthesis of the assessment results is the final stage of AHP. This synthesis is the sum of the weights obtained by each choice in each criterion after being weighted by these criteria. The equation can be written as follows:

$$
\begin{aligned}
& \text { bop }_{\mathrm{i}}=\sum \text { ni }-1 \mathrm{bo}_{\mathrm{ij}} \cdot \mathrm{bc}_{\mathrm{j}} \\
& \text { bop }_{\mathrm{i}}=\text { value } / \text { weight for choice to } \mathrm{i} \\
& \text { bo }_{\mathrm{ij}}=\text { alternative weight } \mathrm{ij} \\
& \mathrm{bc}_{\mathrm{j}}=\text { criteria weight } \mathrm{j}
\end{aligned}
$$

\section{Results and discussion}

\subsection{Overview of Tegal Regency}

Tegal Regency is one of the regencies in Central Java Province with Slawi as its the capital city. Tegal Regency is located in $108^{\circ} 57^{\prime} 6^{\prime \prime}$ until $109^{\circ} 21^{\prime} 30^{\prime \prime}$ East Longitude and between $6^{\circ} 50^{\prime} 41^{\prime \prime}$ until $7^{\circ} 15^{\prime} 30^{\prime \prime}$ South Latitude

Tegal Regency has some borders, i.e.

North Side : Tegal Municipality dan Java Sea

East Side : Pemalang Regency

South Side : Brebes Regency

West Side : Brebes Regency and Banyumas Regency

Tegal Regency administratively has 18 sub-districts which have 281 villages and kelurahan. The guidance in dividing Tegal Regency administrative regions is Law No13 of 1950 about Formation of Regency Areas in Central Java Province. In 1986 there was the division and borders changing between Tegal Regency and Tegal Municipality based on Government Regulation Number 7 of 1986 about Change of Boundary of the Tegal District Level II and Tegal District Level II District. The sub-district having the widest region is Bumijawa $(8,856 \mathrm{Ha}$.) and the smallest sub-district is Slawi $(1,389$ Ha.). 


\subsection{The Analysis of the Strategy in Prioritizing the Sectores and Policies of Green Budgeting in Tegal Regency Regional Government.}

Based on the results of the questionnaire the value of consistency is less than $10 \%$. This shows that the value can be used as the basis for prioritizing the environmental aspects and budget policies in Tegal Regency. The results of data processing using the Expert Choice software obtained criteria and alternative values in determining the priority of environmental-based budget aspects and policies in Tegal Regency. The ranking can be seen in table 8

Table 8. The priority value for sector criteria

\begin{tabular}{|l|l|}
\hline Criteria & Persentage \\
\hline Actual & $16,3 \%$ \\
\hline Urgent & $49,0 \%$ \\
\hline Significant & $23,1 \%$ \\
\hline Consistent & $11,6 \%$ \\
\hline
\end{tabular}

Based on table 8 , it can be seen that the criteria are the main criteria, followed by significant, actual and consistent criteria.

The next step is to rank the alternatives. The results of the questionnaire from the key person are processed with the Software Expert Choice. The results of data processing from the Software Expert Choice can be seen in Table 9 and Table 10

Tabel 9. Priority values for Alternative aspects

\begin{tabular}{|c|l|c|c|}
\hline No & \multicolumn{1}{|c|}{ Alternative } & Value (\%) & Rank \\
\hline 1 & Agriculture & 5.5 & 7 \\
\hline 2 & Infrastructure & 9.0 & 6 \\
\hline 3 & City & 10.1 & 5 \\
\hline 4 & Fisheries & 5.1 & 8 \\
\hline 5 & Industry & 17.4 & 2 \\
\hline 6 & Tourism & 3.9 & 9 \\
\hline 7 & Transportation & 12.2 & 3 \\
\hline 8 & Waste & 26.2 & 1 \\
\hline 9 & Water & 10.6 & 4 \\
\hline
\end{tabular}

Based on the results in table 9, the waste aspect is the top priority in the environment-based budget in Tegal Regency. This happens because in Tegal Regency is an emergency rubbish experience. The problem of waste is very complex because the problem is in the source of garbage up to waste management. Besides garbage the problem problems of metal waste also become an environmental problem in Tegal Regency. The second rank is the industry aspect. Because of the problem of hazardous waste that pollutes the environment. As happened in Margasari Subdistrict where the raw material for burning the limestone industry is hazardous waste. Apart from burning raw materials, the limestone industry also produces smoke that pollutes the air

Tabel 10. Priority values for Alternative aspects

\begin{tabular}{|c|l|c|c|}
\hline No & \multicolumn{1}{|c|}{ Alternative } & $\begin{array}{c}\text { Value } \\
(\mathbf{\%})\end{array}$ & Rank \\
\hline 1 & $\begin{array}{l}\text { Developing and expanding the } \\
\text { organic farming region }\end{array}$ & 5,8 & 7 \\
\hline 2 & $\begin{array}{l}\text { Constructing a pedestrian and green } \\
\text { line on the sidewalks }\end{array}$ & 7,8 & 6 \\
\hline 3 & Constructing Green Open Space & 9,6 & 5 \\
\hline
\end{tabular}

\begin{tabular}{|c|l|c|c|}
\hline 4 & Conserving coral reefs & 5,2 & 8 \\
\hline 5 & $\begin{array}{l}\text { Hazardous and Toxic Substances } \\
\text { Waste Management }\end{array}$ & 17,5 & 2 \\
\hline 6 & Developing eco-tourism & 4,9 & 9 \\
\hline 7 & $\begin{array}{l}\text { Improving public transportation } \\
\text { facilitations }\end{array}$ & 13,5 & 3 \\
\hline 8 & Procurement of garbage trucks & 24,2 & 1 \\
\hline 9 & $\begin{array}{l}\text { Procurement of Rural Drinking } \\
\text { Water Installation Facilities and } \\
\text { Infrastructure }\end{array}$ & 11,5 & 4 \\
\hline
\end{tabular}

Based on table 10, it can be seen that the procurement of garbage trucks is ranked first with $24.2 \%$. This policy is a priority because Tegal Regency is experiencing a solid waste emergency. In various landfills, there is a pile of garbage. As a result of the accumulation of solid waste, it causes many problems such as odor and becomes a source of various diseases. The second level in the environment-based budget policy in Tegal Regency is the Hazardous and Toxic Substances Waste Management policy. This happens because the problem of hazardous waste has become an issue that is getting enough attention. In Margasari sub-district at the beginning of 2019 illegal waste factories have been found which have polluted river water. In Adiwerna the sub-district as the center of the metal industry, lead metal waste has contaminated the soil in the area.In the third rank improvement, the public transportation policy becomes a policy that must be done. This is because to reduce water pollution in the Tegal Regency area.

\section{Conclusion}

In determining the priority aspects in environmental-based planning budgets in the Tegal District Government, the waste sector was obtained as a priority sector in environment-based budget planning. Followed in second place is the industrial sector. The third place is the transportation sector.

The waste sector is a priority sector because of waste problems, and is increasingly alarming and requires immediate handling, especially the problem of sources of waste and waste management. The temporary landfill is also a major issue that needs serious attention from the Tegal Regency Government. This happens because of the accumulation of solid waste in Tegal Regency's temporary landfills.

To overcome environmental problems in Tegal Regency, there must be a solution to overcome these problems. It was found that the garbage truck procurement program was the first priority to address environmental problems in Tegal Regency. The second rank in environmental-based budget policy is hazardous and toxic substances, waste management policy and ranked third in improving public transportation facilitations policy

\section{References}

1. Tempo, "PBB:Jumlah Penduduk Dunia 9,8 Milyar tahun 2050"2017 [online] available. https://dunia.tempo.co/read/886917/pbb-jumlahpenduduk-dunia-98-miliar-tahun-2050 [Accessed: 06-May-2019]. 
2. I. Mukhlis, Eksternalitas, Pertumbuhan Ekonomidan Pembangunan Berkelanjutan dalam Perspektif Teoritis. Jurnal Ekonomi Bisnis, 14, 23 (2009)

3. A.F. Faqih, Model kebijakan anggaran berbasis lingkungan (green budgeting) di pemerintah Provinsi Jawa Tengah, Semarang: Universitas Diponegoro (2017)

4. DLH, Informasi Kinerja Pengelolaan Lingkungan Hidup Daerah Kabupaten Tegal 2017, Slawi: Dinas Lingkungan Hidup (2018).

5. S.P. Hadi, Bunga Rampai Manajemen Lingkungan, Yogyakarta: Thafa Media (2014)

6. A.S. Keraf, Etika Lingkungan Hidup, Jakarta: PT Kompas Media Nusantara (2010).

7. S. Y .Pan, M. Gao, H. Kim, K. J. Shah, S. L. Pei, and P. C. Liang, Advances and challenges in sustainable tourism toward a green economy, Science of the Total Environment, Elsevier B.V., 635, pp. 452-469. (2018)

8. S. Kusumadewi and H. Purnomo, Aplikasi Logika Fuzzy untuk Pendukung Keputusan, Yogyakarta:Graha Ilmu (2010)

9. Sugiyono, Metode Penelitian Kuantitatif, Kualitatif dan R\&D, Bandung: PT Alfabet (2016)

10. T. L. Saaty, Pengambilan Keputusan Bagi Para Pemimpin, Jakarta: PT. Pustaka Binaman Pressindo (1991)

11. A.A. Yusuf, Green Economy di Indonesia: Sekarang dan Prospek ke depan. Disampaikan pada Semiloka Green Economy, Jakarta: Kementerian PPN/Bappenas (2011) 